\title{
ANTI-INFLAMMATORY STUDY OF ANREDERA CORDIFOLIA LEAVES AND CENTELLA ASIATICA HERBS AND ITS COMBINATIONS USING HUMAN RED BLOOD CELL-MEMBRANE STABILIZATION METHOD
}

\author{
ENTRIS SUTRISNO ${ }^{1,2 *}$, KETUT ADNYANA I ${ }^{1}$, ELIN YULINAH SUKANDAR ${ }^{1}$, IRDA FIDRIANNY ${ }^{1}$, WIDHYA ALIGITA ${ }^{2}$
}

${ }^{1}$ Department of Pharmacology, Bandung Institute of Technology, Jl. Ganesa No. 10 Bandung, Indonesia. ${ }^{2}$ Department of Clinical and Community Pharmacy, Bandung School of Pharmacy, Jl. Soekarno Hatta No. 754, Bandung, Indonesia. Email: tries18@gmail.com

Received: 01 April 2016, Revised and Accepted: 09 April 2016

\section{ABSTRACT}

Objective: Inflammation is body reactions in response to tissue injury and infection. In 2011, non-steroidal anti-inflammatory drug (NSAID) was the highest demand drug in Indonesia. However, long-term treatment using NSAID can cause several side effects to cardiovascular and digestive system. This research aimed to investigate anti-inflammatory properties of binahong leaves (Anredera cordifolia) and pegagan herbs (Centella asiatica)

Methods: Ethyl alcohol extract of $A$. cordifolia leaves and C. asiatica herbs was evaluated for its anti-inflammatory properties using human red blood cell (RBC) - membrane stabilization assay. The extract concentrations used in this study was 100, 200, 400, and 800-ppm, and apigenin and asiaticoside concentration were 1, 2, 3, 4, 5, 6, 10, and $100 \mathrm{ppm}$. Diclofenac natrium (DN) was used as a standard drug.

Results: The results showed that A. cordifolia extract (ACE) alone, C. asiatica extract (CAE) alone, and the combination of ACE and CAE could inhibit the hemolysis of RBC in hypotonic solution. The optimum concentration for ACE alone was $100 \mathrm{ppm}$; for CAE alone was $400 \mathrm{ppm}$; and for the combination of ACE and CAE was $50 \mathrm{ppm}$ and $50 \mathrm{ppm}$, respectively. Apigenin and asiaticoside in concentration of 1-10 ppm showed more than $97 \%$ inhibition of hemolysis. DN as a standard drug showed optimum inhibition at concentration of $400 \mathrm{ppm}$.

Conclusion: The ethyl alcohol extract of A. cordifolia leaves and C. asiatica herbs showed anti-inflammatory activity, both as a single treatment or as combinations, and apigenin and asiaticoside were responsible for anti-inflammatory activity in C. asiatica.

Keywords: Anti-inflammation, Human red blood cell - membrane stabilization, Anredera cordifolia, Centella asiatica.

(C) 2016 The Authors. Published by Innovare Academic Sciences Pvt Ltd. This is an open access article under the CC BY license (http://creativecommons. org/licenses/by/4. 0/) DOI: http://dx.doi.org/10.22159/ajpcr.2016.v9i5.11973

\section{INTRODUCTION}

Inflammation is body reactions in response to tissue injury and infection. When inflammation occurred, blood element, for example, leukocyte, and chemical messenger accumulated at injured area. There are five characteristics of inflammation: Redness, swelling, the rise of temperature, pain, and loss of function [1]. Non-steroidal antiinflammatory drug (NSAID) is one of the most common medications for inflammation. This drug acts by stabilizing lysosome membrane and inhibiting hydrolytic enzyme release. In 2011, NSAID was the highest demand drug in Indonesia. However, long-term treatment using NSAID can cause several side effects to the cardiovascular and digestive system [2]. Hence, it is an opportunity to find an alternative medicine for inflammation. Herbal medicine is one of the most potential drug resources, and Indonesia has a very large biodiversity.

Anredera cordifolia and Centella asiatica are commonly used as a traditional medicine in Indonesia. A. cordifolia, belongs to Basellaceae family [3], known as Binahong in Indonesia, has been evaluated for its analgesic activity [4], anti-hyperlipidemic activity [5], and in improving kidney failure [6]. Formulation for A. cordifolia as wound healing gel has been evaluated [7]. Whereas C. asiatica, belongs to Apiaceae family, known as pegagan in Indonesia, traditionally used to heal wound and improve appetite [8]; it's also used for its activity as diuretics, hemostatic, and anti-infection [9]. This plant has been reported having activity including antioxidant, antimicrobial, cytotoxic, neuroprotective, anti-inflammatory, anti-diabetic, antiulcer, and wound healing. The bioactive constituents of these plants are the triterpenic acid (asiatic acid and madecassic acid), triterpenic saponin (madecassoside and asiaticoside), flavonoids (quercetin, kaemferol, catechin, rutin, apigenin, and naringin), and other phenolic compounds $[10,11]$.
Based on the traditional use and another study, the combination of these two plants was thought to be effective as an anti-inflammatory agent. Moreover, the combination of these two plant extracts in inhibiting inflammation has never been investigated before. Hence, the aim of this study was to evaluate anti-inflammatory activity of $C$. asiatica and A. cordifolia, as a single treatment or as combinations.

\section{METHODS}

Identification and authentication of plant materials

C. asiatica and A. cordifolia plants were obtained from Manoko Botanical Garden, Bandung, West Java, Indonesia. Fresh plants were dried at 50$60^{\circ} \mathrm{C}$ and then grinded into small pieces. Plant identity's authentication was performed by Herbarium Bandungense, School of Natural Science and Technology, Bandung Institute of Technology.

Preparation of ethanolic extract of $\boldsymbol{C}$. asiatica About $200 \mathrm{~g}$ dried herbs of C. asiatica was macerated using $2 \mathrm{~L}$ ethanol [12]. The mixture was filtered using a filter paper, and the filtrate was concentrated using rotary vacuum evaporator at $60^{\circ} \mathrm{C}$.

\section{Preparation of ethanolic extract of $A$. cordifolia}

About $200 \mathrm{~g}$ dried leaves of $A$. cordifolia was macerated using $2 \mathrm{~L}$ ethanol [7]. The mixture was filtered using a filter paper, and the filtrate was concentrated using rotary vacuum evaporator at $60^{\circ} \mathrm{C}$.

\section{Membrane stabilization (MS) assay}

Anti-inflammatory activity was evaluated using human red blood cell MS (HRBC-MS) assay [13]. Blood was collected from healthy volunteer who did not consume any NSAID for 2 weeks before the experiment. The collected blood was mixed with a silver solution in equal amount. The mixture was centrifuged in $3000 \mathrm{rpm}$ and obtained packed cell 
was washed with isotonic solution $(\mathrm{NaCl} 0.9 \%)$ in equal volume. The mixture was once again being centrifuged and obtained packed cell was made into $10 \%$ suspension in isotonic solution $(\mathrm{NaCl} 0.9 \%)[14,15]$.

The evaluated mixture was made by mixing $2 \mathrm{ml}$ of hypotonic solution $(\mathrm{NaCl} 0,36 \%), 1 \mathrm{ml}$ of phosphate buffer solution (pH 7.4), $0.5 \mathrm{ml}$ of HRBC $10 \% \mathrm{v} / \mathrm{v}$ in isotonic solution $(\mathrm{NaCl} 0.9 \%)$, and $1 \mathrm{ml}$ of evaluated sample (C. asiatica extract [CAE], A. cordifolia extract [ACE], apigenin, asiaticoside, or diclofenac natrium [DN]). The concentration of extract and DN were $100,200,400$, and $800 \mu \mathrm{g} / \mathrm{ml}$. Whereas apigenin and asiaticoside concentration were $1,2,3,4,5,6,10$, and $100 \mu \mathrm{g} / \mathrm{ml}$. DN was used as a standard drug. This mixture was incubated at $37^{\circ} \mathrm{C}$ for 30 minutes, and then being centrifuged. The supernatant was collected and being measured using spectrophotometer ultraviolet-visible at $560 \mathrm{~nm}[15,16]$.

The percentage of hemolysis was calculated using following equation: \%Inhibition of hemolysis $=100 \%-\frac{(\text { Sampleabsorbance })}{(\text { Controlabsorbance })} \times 100 \%$

\section{RESULTS AND DISCUSSION}

The extract's percentage of inhibition of hemolysis was shown in Fig. 1.

From the experiment, the extract showed an ability to inhibit hemolysis of RBC in hypotonic solution. HRBC membrane shows similarity with lysosome membrane. During inflammation, the lysosomic enzyme is released and therefore producing several characteristics of inflammation. The ability to stabilize lysosome membrane is thought can prevent inflammation. This is the NSAID's mechanism of action as anti-inflammatory agent [13].

According to Fig. 1, CAE at concentration 100 ppm showed 78\% inhibition of hemolysis. The increasing concentration enhanced the ability to stabilize the RBC membrane from hemolysis. The highest percentage of inhibition was shown at concentration $400 \mathrm{ppm}$ with $91 \%$ inhibition. DN, which was used as a standard drug, showed $92.12 \%$ inhibition at the same concentration. Based on these data, C. asiatica was proved to be having an anti-inflammatory activity. Moreover, this result was comparable with another study which also evaluated its antiinflammatory properties $[17,18]$.

Asiaticoside and apigenin also showed the ability to inhibit the hemolysis of RBC (Fig. 2).

Apigenin, which was one of the flavonoid compounds in C. asiatica, showed more than $90 \%$ inhibition of hemolysis in concentration of 1-100 ppm. As for asiaticoside, which was the triterpene compound in C. asiatica, showed similar percentage of inhibition to apigenin in concentration of 1-10 ppm. However, at concentration of $100 \mathrm{ppm}$, asiaticoside showed declining in percentage of hemolysis inhibition to $45 \%$. From these data, it was proved that the active compound which was responsible for anti-inflammatory activity in $C$. asiatica was apigenin and asiaticoside.

As for ACE, the highest percentage of inhibition was achieved at concentration of $100 \mathrm{ppm}$ with $81 \%$ inhibition of hemolysis, which was the lowest evaluated concentration. And raising in concentration affected in decreasing the extract's ability to stabilize the RBC membrane from hemolysis. DN as a standard drug showed $12.94 \%$ inhibition at the same concentration. According to these data, A. cordifolia showed anti-inflammatory activity. From another study, it was known that A. cordifolia contain oleanolic acid which has anti-inflammatory activity that can reduce pain in burns [19].

When these two extracts were combined, the result showed that the maximum inhibition of hemolysis activity was shown in combination of $50 \mathrm{ppm}$ CAE and $50 \mathrm{ppm}$ ACE, which was the lowest concentration

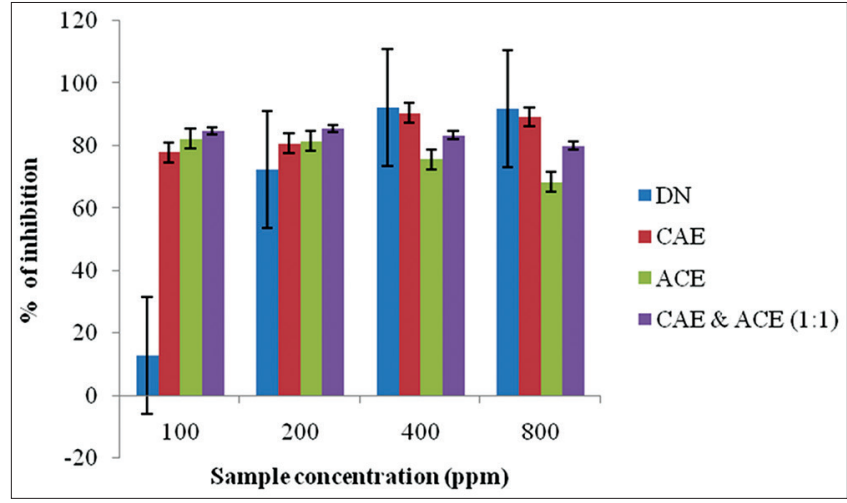

Fig. 1: Percentage of hemolysis inhibition of extracts.

DN: Diclofenac natrium, CAE: Centella asiatica extract, ACE: Anredera cordifolia extract, $\mathrm{n}=2$ per group

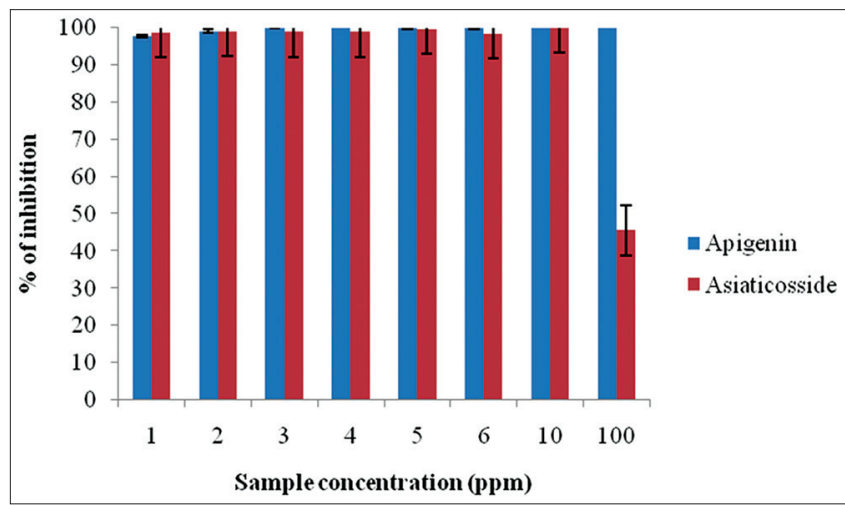

Fig. 2: Percentage of hemolysis inhibition of apigenin and asiaticoside, $n=2$ per group

of the combinations. And rising concentration in combination did not show a significant elevation in inhibiting hemolysis.

\section{CONCLUSION}

It was concluded that CAE and ACE had the anti-inflammatory activity, both as a single treatment or as combinations; and apigenin and asiaticoside were responsible for anti-inflammatory activity in $C$. asiatica.

\section{REFERENCES}

1. Joyce KL, Hayes ER. Farmakologi Pendekatan Proses Keperawatan Jakarta: Penerbit Buku Kedokteran ECG; 1996.

2. McGettigan P, Henry D. Use of non-steroidal anti-inflammatory drugs that elevate cardiovascular risk: An examination of sales and essential medicines lists in low-, middle-, and high-income countries. PLoS Med 2013;10(2):e1001388.

3. Badan Pengawas Obat dan Makanan Republik Indonesia (BPOM RI). Taksonomi Koleksi Tanaman Obat Kebun Tanaman Obat Citeureup. Vol 1. Jakarta: BPOM RI Direktorat Obat Asli Indonesia; 2008.

4. Yuziani, Harahap U, Karsono. Evaluation of analgesic activities of ethanolic extract of Anredera cordifolia (Ten) steenis leaf. Int J PharmTech Res 2014;6(5):1608-10.

5. Wahjuni S. Anti-hypercholesterolemia of Anredera cordifolia in hypercholesterolemia rat wistar through decrease of malondialdehyde and 8-hydroxy-diguanosine. Indones J Biomed Sci 2014;8(1):4-7.

6. Sukandar EY, Fidrianny I, Adiwibowo IF. Efficacy of ethanol extract of Anredera cordifolia $(\mathrm{Ten})$ steen is leaves on improving kidney failure in rats. Int J Pharmacol 2011;7:850-5.

7. Yuliani SH, Fudholi A, Pramono S, Marchaban. The effect of formula to physical properties of wound healing gel of ethanolic extract of binahong (Anredera cordifolia (Ten) Steenis). Int J Pharm Sci Res 
2012;3(72):4254-9.

8. Kasahara YS. Medicinal Herbs Index in Indonesia. Jakarta: PT Eisai Indonesia; 1986.

9. Dalimartha S. Atlas Tumbuhan Obat Indonesia Jilid 2. Jakarta: Trubus Agriwidaya; 2000.

10. Seevaratnam V, Banumathi P, Premalatha MR, Sundaram SP, Arumugam T. Functional properties of Centella asiatica (L.): A review. Int J Pharm Pharm Sci 2012;4 suppl 5:8-14

11. Hashim, P. Mini review: Centella asiatica in food and beverage applications and its potential antioxidant and neuroprotective effect. Int Food Res J 2011;18(4):1215-22.

12. George M, Joseph L, Ramaswamy. Anti-allergic, anti-pruritic, and anti-inflammatory activities of Centella asiatica extracts. Afr J Tradit Complement Altern Med 2009;6(4):554-9.

13. Chowdhury A, Azam S, Jainul MA, Faruq KO, Islam A. Antibacterial activities and in vitro anti-inflammatory (membrane stability) properties of methanolic extracts of Gardenia coronaria leaves. Int J Microbio 2014. doi: org/10.1155/2014/410935.
14. Gadamsetty G, Maru S, Sarada NC. Antioxidant and anti-inflammatory activities of the methanolic leaf extract of traditionally used medicina plant Mimusops elengi L. J Pharm Sci Res 2013;5(6):125-30.

15. Anosike CA, Obidoa O, Ezeanyika LU. Membrane stabilization as mechanism of the anti-inflammatory activity of methanol extract of garden egg (Solanum aethiopicum). Daru 2012;20(1):76.

16. Rajalakshmi GR, Harindran J. Anti-inflammatory activity of Wrightia tinctoria leaves by membrane stabilization. Int J Pharm Sci Res 2012;3:497-9.

17. Chippada SC, Volluri SS, Bammidi SR, Valangapati M. In vitro antiinflammatory activity of methanolic extract of Centella asiatica by HRBS membrane stabilisation. Rasayan J Chem 2011;4(2):457-60.

18. Saha S, Guria T, Singha T, Maity TK. Evaluation of analgesic and antiinflammatory activity of chloroform and methanol extracts of Centella asiatica linn. ISRN Pharmacol 2013;2013:789613.

19. Moura-Letts G, Villegas LF, Marçalo A, Vaisberg AJ, Hammond GB In vivo wound-healing activity of oleanolic acid derived from the acid hydrolysis of Anredera diffusa. J Nat Prod 2006;69(6):978-9. 